\title{
Editorial
}

\section{Poesia e juventude em Machado de Assis}

\section{Poetry and Youth in Machado de Assis}

\section{HÉLIO DE SEIXAS GUIMARÃES}

Universidade de São Paulo

São Paulo, São Paulo, Brasil

Este número 30 da Machado de Assis em linha traz o signo da poesia e da juventude de Machado de Assis, que têm despertado atenção crescente entre estudiosos do autor.

O artigo de abertura, de Pablo Rocca, da Universidad de la República, de Montevidéu, Uruguai, destaca as tentativas de aproximação do jovem jornalista e poeta dos seus pares da América Hispânica. Em "Diálogo entrecortado: Machado de Assis, a língua e a poesia hispano-americana", Rocca remete ao conceito de "anacronismo deliberado", de Jorge Luis Borges, para mostrar como as polêmicas sobre a autonomia da língua literária das excolônias espanholas, que Machado acompanhou de seu observatório carioca, rebatem na visão de língua literária expressa em escritos como "Instinto de nacionalidade" (1873).

Em "A história de Francisco Gonçalves Braga: o primeiro mestre de Machado De Assis”, Wilton José Marques, da Universidade Federal de São Carlos, faz uma minuciosa reconstituição das relações pessoais e literárias de Machado com o poeta português, que viveu no Rio de Janeiro por seis anos e é considerado como o "primeiro mestre" do autor de Crisálidas (1864), referido em vários de seus escritos.

As relações entre editores e poetas, e as estratégias de reconhecimento e valorização recíproca, são assunto também de "Um caso de legitimação: Teixeira e Sousa por Machado de Assis (e Paula Brito)”. Cristiane Nascimento Rodrigues, doutoranda na Universidade Federal de São Carlos, mostra o que seria a ação coordenada de Machado e seu primeiro editor, Paula Brito, no 
elogio de Teixeira e Sousa, com a escrita e publicação do poema "O gênio adormecido" (1855).

A respeito desses três primeiros textos, cabe lembrar o que Antonio Candido escreveu sobre a pesquisa excepcional de Jean-Michel Massa a respeito das primeiras décadas da vida literária de Machado de Assis: "Um mundo apenas vislumbrado saiu então da sombra, delineando o ambiente no qual começou a carreira de Machado de Assis, cuja biografia se completava assim pela história do seu amadurecimento intelectual." (CANDIDO, apud MASSA, 2009, p. 12)

Fora do terreno da poesia, mas ainda no campo dos escritos pré-Brás Cubas, Priscila Salvaia, doutora pela Universidade Estadual de Campinas, explora em "Sobre amor e "fria eleição do espírito" as relações entre a trajetória de Guiomar, de $A$ mão e a luva, e os discursos sobre a condição feminina dos inícios da década de 1870 veiculados por periódicos como $O$ Globo, no qual o romance saiu pela primeira vez como romance-folhetim.

Por fim, "O lugar das ideias liberais nas Memórias póstumas de Brás Cubas", de Elvis Paulo Couto, procura caracterizar os modos como a imaginação literária de Machado de Assis figura o "triunfo do liberalismo" no romance. Com isso, Couto questiona a leitura do romance como crítica contundente aos usos e abusos das ideias liberais pela elite brasileira oitocentista, defendida por Roberto Schwarz em Um mestre na periferia do capitalismo.

A seção "Da tradição crítica", que tradicionalmente abre a revista, homenageia neste $30^{\circ}$ número Lêdo Ivo, com a publicação de "Os braços de Dona Severina”. No artigo de 1963, o poeta, ficcionista e ensaísta traça linhas de continuidade entre "Uns braços" e "Missa do galo", destacando o que há de poético na prosa machadiana. Como destaca Marcelo Diego, da Universidade Federal do Rio de Janeiro, na sua apresentação do ensaio, Ivo mostra nesse texto a força do seu talento ensaístico, ao desvelar as relações entre jogo erótico e fome de absoluto na escrita machadiana.

Boas leituras!

\section{Referência}

CANDIDO, Antonio. "Prólogo". Apud MASSA, Jean-Michel. A juventude de Machado de Assis, 1839-1870: ensaio de biografia intelectual. Trad. Marco Aurélio de Moura Matos. $2^{\text {a }}$ ed. São Paulo: Editora UNESP, 2009. 